\title{
Erzincan'dan Tek Nefli İki Kilise: Değirmenliköy ve Yaylabaşı Kiliseleri
}

\section{Two Churches with Single Nave from Erzincan: Değirmenliköy and Yaylabaş1 Churches}

\author{
Demet Okuyucu Yılmaz \\ Dr. Öğr. Üyesi, Atatürk Üniversitesi Edebiyat Fakültesi Sanat Tarihi Bölümü \\ email: demet@atauni.edu.tr (DORCID ID: https://orcid.org/0000-0002-5533-8397
}

Atıf (APA 6)/To cite this article

Okuyucu Yılmaz, D. (2019). Erzincan'dan tek nefli iki kilise: Değirmenköy ve Yaylabaşı kiliseleri. Atatürk Üniversitesi Güzel Sanatlar Enstitüsü Dergisi, 43, 234-247. doi: https://doi.org/10.32547/ataunigsed.606483

Makale Gönderim Tarihi/Received: 19/08/2019

Makale Kabul Tarihi/Accepted: 23/09/2019

Makale Yayın Tarihi/Published: 26/10/2019

Research Article/Araştırma Makalesi

\section{Öz}

Fırat nehrinin yukarı havzasında, bir ova içerisine kurulan ve Doğu Anadolu bölgesinin önemli sehirlerinden biri olan Erzincan'ın bulunduğu yerde ilk yerleşimlerin tarihi milattan önce 3. bin yıla kadar inmektedir. Tarihi süreci içeresinde çok sayıda medeniyet ve devletin çerçevesine giren şehirde mimari faaliyetler de paralel olarak varlık göstermiştir. Gayrimüslim milletlerin Anadolu coğrafyasında yaşam sürmelerinin doğal bir sonucu olarak Hristiyan dini mimarisi, örneklerini Erzincan ve çevresinde de sunmuştur. Bu çalışmada Erzincan İli merkez ilçesinde bulunan tek nefli planlı iki kilise plan, mimari ve süsleme özellikleri bakımından incelenmiştir. Yapılar Erzincan ve Anadolu'daki benzer özelliklere sahip yapılarla karşılaştırılarak bir değerlendirmeye tabi tutulmuştur.

Anahtar Kelimeler: Erzincan, Doğu Anadolu Bölgesi, Ermeni, Kilise, Tek Nef, Haçkar

\begin{abstract}
In the upper basin of the Euphrates, Erzincan being one of the most important cities of the Eastern Anatolia region, was founded in a plain and the history of the first settlements dates back to the 3rd millennium BC. Architectural activities have been simultaneously presented in the city which has been authorized by numbers of civilisations and governments during the historical timeline. As a natural consequence of the non-Muslim nations' living in Anatolia, in Christian religious architecture, examples have also been presented in and around Erzincan. In this study, two churches with a single nave in the central district of Erzincan have been examined in terms of their architectural and decorative features. The structures have been compared and evaluated with those of the structures having similar characteristics in Erzincan and Anatolia.
\end{abstract}

Keywords: Erzincan, East Anatolian Region, Armenian, Church, Single Nave, Khachkar

\section{Giriş}

Doğu Anadolu bölgesinin önemli şehirlerinden biri olan Erzincan tarihi hakkında müslim ve gayri müslim çok sayıda kaynak bulunmaktadır.

İlkçağda Eriza (Miroğlu, 1995, s. 318), Grek kaynaklarında Aziris (Justiniapolis) (Kara, 2016, s. 569), Ermeni Kaynaklarında Erez, Erzng, Erznga, Bizans Kaynaklarında Aringam, Arıngan, Arsengen, Arsingan, Erzingan, Arap Kaynaklarında Erzencân, Erzenkân, Erzinkân diye anılan şehrin ismi Osmanlı kaynaklarında Erzincân olarak kaydedilmiş, bazı kaynaklarda ise Arzingan, Arzincân, Erzinjan, Erz-i Cân şeklinde yazılmıştır. (Parlak, 2016, s. 356). Evliyâ Çelebî, (Evliya Çelebi, 2010, s. 188), Urfalı Mateos (Mateos, 1987, s. 81-82), Marco Polo (Polo, 2003, s. 77), Ruj Gonzalez De Clavijo (Clavijo, 1975, s. 67), İbni Batuta ve İbni Haldun Erzincan'dan bahseden önemli kaynaklardan bazılarıdır (Parlak, 2016, s. 358-359).

Erzincan 1071 Malazgirt Savaşı sonrasında Mengüceklilerin idaresine, 1514 yılında ise Osmanlı hakimiyetine geçmiştir. Tarihi kayıtlara göre şehirde, dağılımı mahallelere göre değişiklikler göstermekle beraber, Müslüman ve gayri müslim nüfus birlikte yaşamışlardır (İnbaşı, 2009, s. 190-194).

Osmanlı İmparatorluğu, yönetimine giren yerlerdeki milletlere hangi inanç ve mezhepten olursa olsun geniş bir din ve vicdan özgürlüğü sağlanmıştır. Alınan şehirlerde fethin nişanesi olarak camiye çevrilen kiliseler dişındaki ibadethaneler ait oldukları cemaatlere bırakılmış, bunların muhafazasına da özen gösterilmiștir. Şehirlerde Müslüman nüfusunun artmasının doğal sonucu olarak da yeniden kilise, havra vb. inşasına izin verilmemiștir (Turan, 1963, s. 170-171). Deprem ve yangın gibi durumlarda tamamen yıkılan ibadethaneler yeniden inşa edilmiştir. İbadethanelerin onarımı için ise gayrimüslim cemaatlerin mütevelli heyetlerine Babıali'den izin almaları şartı koşulmuştur (Bozkurt, 1989, s. 22).

Osmanlı devletinde gayrimüslim ibadethaneleri üzerindeki kurallar İslam hukuku hükümlerine göre düzenlenmiştir (Ercan, 2001, s. 233). 3 Kasım 1839'da ilan edilen Tanzimat Fermanı ile ilk kez İslam hukuku dışına çıkılmış (Ubicini, 2010, s. 27-28), 18 Şubat 1856 Islahat Fermanı ile de yeniden kilise inşa edilmesi mümkün 
olmuştur (Bozkurt, 1989, s. 56). Yaşanan bu gelişmeler neticesinde 19. yüzyılda Osmanlı topraklarında Ermeni ve Rumlar tarafından gerek başkent İstanbul'da gerekse Anadolu'da çok sayıda yeni kilise inşa edilmiştir (Pekak, 2009, s. 253.

Erzincan, Osmanlı döneminde pek çok bölgede olduğu gibi müslim ve gayrimüslim tebaanın ve farklı etnik grupların bir arada yaşadığı bir yerleşim yeri olmuştur. Erzincan ve çevresinde Müslüman Türklerle birlikte Rumlar ve Ermeniler de yaşamıștır. Nüfus sayımı verilerine göre Ermeniler Rumlardan daha fazladır (Akyel, 2016, s. 59). Ancak ülkenin diğer yerlerinde olduğu gibi burada da Ermeni nüfus Müslüman nüfusa kıyasla azınlıkta kalmıştır (Sami, 1889, s. 27; Çakaloğlu, 1999, s. 29). Erzincan kazası 19. yüzyılda Erzurum' a bağlı bir sancak durumunda iken toplam nüfusu 210.858 olup bunun 171.472'si Müslümandır (Miroğlu, 1995, s. 321).

Hıristiyanlığın bölgede yayılım göstermesi ve gayrimüslim tebaanın çoğalması neticesinde Erzincan ve çevresinde kilise inşa faaliyetleri erken dönemden 19.yüzyılın sonlarına kadar devam etmiştir.

\section{Yöntem}

Araştırma Betimsel modele dayalıdır. Bu doğrultuda araştırma, Betimsel araştırma modellerinden nitel araştırma yöntemiyle yürütülmüştür. Araştırmada Erzincan İli merkez ilçesinde bulunan tek nefli planlı iki kilise gözlem tekniği kullanılarak plan, mimari ve süsleme özellikleri bakımından incelenmiştir. Yapılar Erzincan ve Anadolu'daki benzer özelliklere sahip yapılarla karşıllaştırılarak değerlendirilmiştir.

\section{Bulgular ve yorum}

\subsection{Değirmenliköy kilisesi}

Yapı Erzincan İli Merkez İlçesine bağlı, Munzurların kuzey etekleri boyunca kurulan köylerden (Şahin, 2017, s. 178) Değirmenliköy'de, Köyiçi mevkiinde yer almaktadır. Ermeni kaynaklarında Dzatküğ/Zetkiğ (Şahin, 2017, s. 178) (Sadköy) olarak da geçen Değirmenliköy’de 628 Ermeni, 440 Türk'ün yaşadığı; 80 öğrencili bir okul ve bir de Meryem Ana Kilisesi'nin varlığı belirtilmiştir (Kevorkian-Paboudjıan, 2013, s. 458). İnşa tarihi hakkında bilgi veren yazıt veya herhangi bir kaynak bulunmayan yapı plan ve mimari özellikleri bakımından 19.yüzyıla tarihlendirilebilir ${ }^{1}$.

Kilise yaklaşık 9.80 x16.90 m. boyutlarında, dikdörtgen bir alan üzerine tek nefli olarak inşa edilmiştir (Görsel 1).

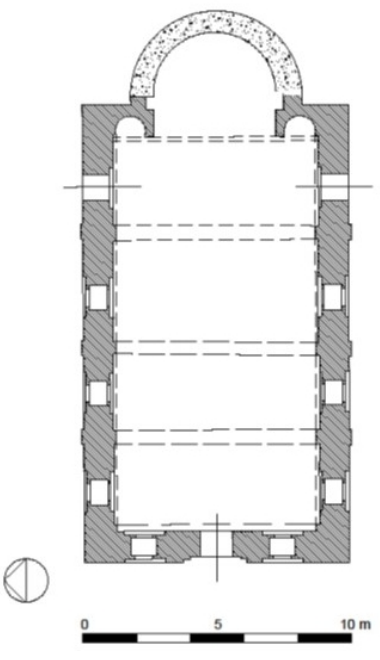

Görsel 1. Değirmenliköy kilisesi planı

Yapının, biri batı cephesinin ortasında, diğerleri kuzeydoğu ve güneydoğu cephelerde olmak üzere üç girişi bulunmaktadır. Kilisenin batı cephesi hareketli ve bezemeli bir cephedir (Görsel 2).

\footnotetext{
${ }^{1}$ Tahir Erdoğan Şahin, Erzincan Yukarı Ülkenin Kadim Cenneti isimli kitabında kilisenin ilk inşa tarihinin belli olmadığını bununla birlikte alt yapı malzemeleri ve bazı öğelerden hareketle 10-11. Yüzyıllara giden bir geçmişinin olabileceğini; son tadilat ve ikmalinin ise 19. Yüzyılda gerçekleştiğini yazmıştır.
} 


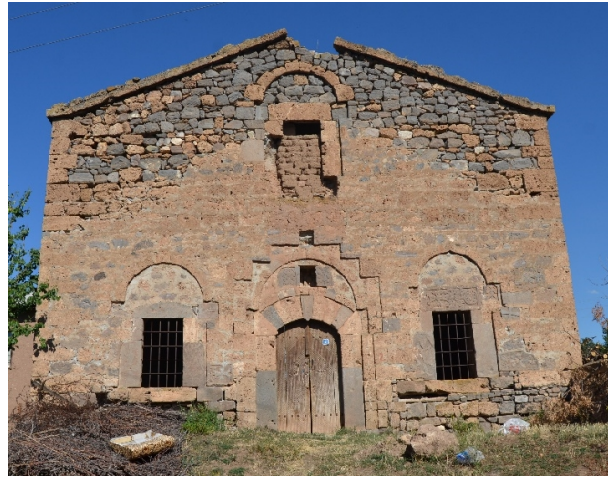

Görsel 2. Değirmenliköy kilisesi batı cephesi genel görünümü

$\mathrm{Bu}$ cephedeki ana giriş basık kemerli olup özenle ele alınmıştır. Genel olarak kademeli haç formlu bir çerçeve içerisine alınan girişin alınlığ 1 ise yüzeysel yuvarlak kemerlidir. Alınlık içerisinde kitabelik bölümü olarak düşünülen yer günümüzde boştur. Boşluğa bakıldığında üst kısımda haç bezemeli bir taş inşa malzemesi olarak kullanılmıștır. Bu bölümün her iki yanında biri oktagon diğeri de Ermeni haçı formunda birer haçlı taş; giriş kemeri kilit taşı yüzeyinde ise basit çiziklerle oluşturulmuş bir Golgotha haçı görülmektedir (Görsel 3).

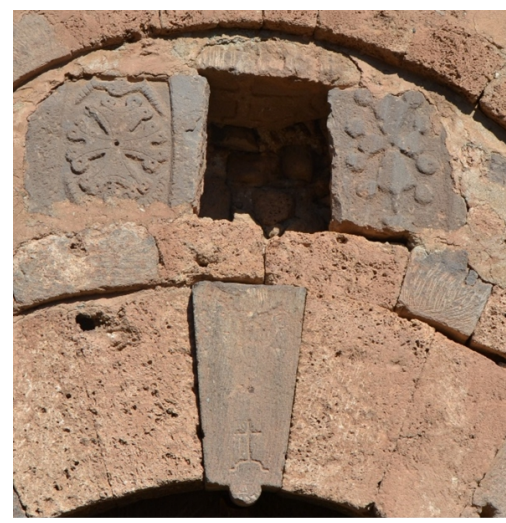

Görsel 3. Değirmenliköy kilisesi girişi detayı

Girişin iki yanında ve üzerinde dikdörtgen formlu birer pencere açılklğına yer verilmiştir. Cephenin sağ ve solundaki pencereler, yüzeysel yuvarlak kemerli alınlıklı çökertilmiş yüzeyler içerisindedir. Sağdaki pencerenin lentosu, lento kenarı, sol sövesi ve çerçevenin hemen dışında; sol pencere lentosunun devamında ve çerçevesinin bitişiğinde haçlı taşlar kullanılmıştır. Bunlardan en özelliklisi lentoda kullanılan zengin bezemeli haçkardır (Görsel 4).

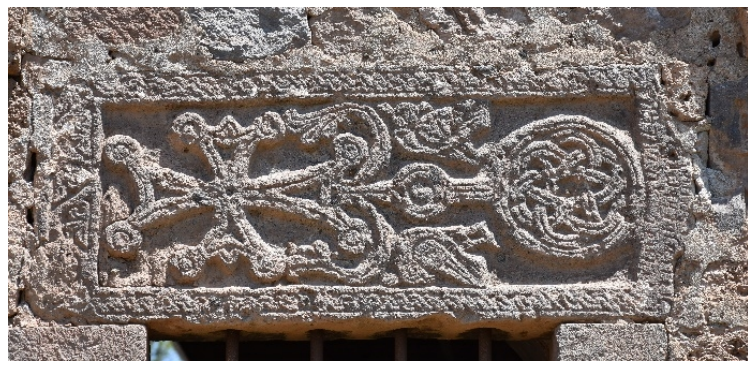

Görsel 4. Değirmenliköy kilisesi pencere lentosu haçkar detayı

Üçgen olarak sonlanan cephenin üst bölümünde yer alan pencere dikdörtgen formlu lentolu ve yuvarlak kör kemerli alınlıklı olup tuğla ile örülerek kapatılmıştır.

Kilisenin doğusunda içten ve dıştan yarım yuvarlak bir apsisin bulunduğu bilinmektedir. 27 Aralık 1939 yılında meydana gelen Büyük Erzincan Depremi tüm kenti, çevre bölge ve illerini etkilemiştir. Bu yıkıcı etkiden Değirmenliköy Kilisesi de etkilenmiş, apsis bu dönemde hasar görmüş ve sonrasında da yıkılmıştır² (Aslay, 2017, s. 120) (Görsel 5).

\footnotetext{
${ }^{2}$ Semi Emrah Aslay yapmış olduğu çalışmasında, teknik analizler sonucunda depremde apsisin yıkılmasa da apsis ile beden duvarları bağlantılarının hasar gördüğünü ve hasarın ilerleyerek apsisi yapının ana gövdesinden kopardığını belirtmiștir.
} 


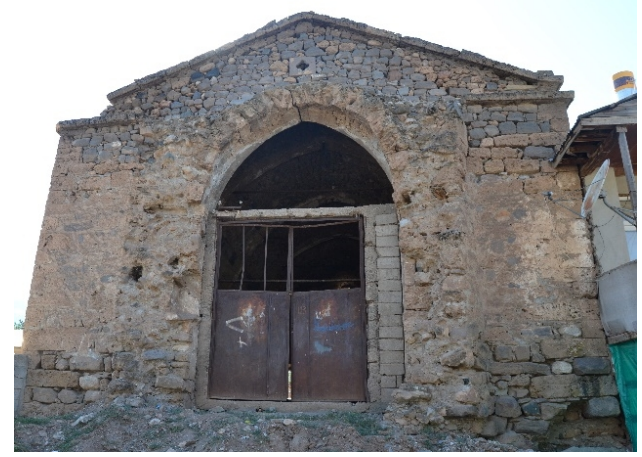

Görsel 5. Değirmenliköy kilisesi doğu cephesi genel görünümü

Apsis duvarından günümüze iki yandan uzanan birer parça ulaşmış, bunlardan güney duvarında kısmen kuzeyde ise bütünüyle mevcut birer litürjik niş açılmıştır. Nişin üst kısmına devşirilen bir haçkar yerleştirilmiş, kemerine denk gelen bölüm dalgalı hatlı bir sivri kemer görüntüsü verilmek suretiyle yeniden şekillendirilmiştir (Görsel 6).

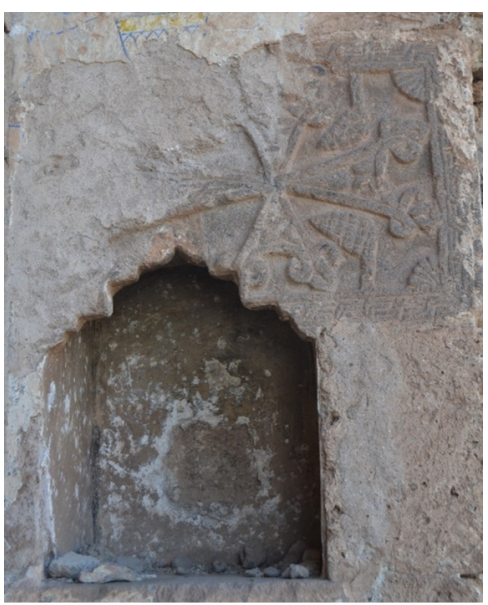

Görsel 6. Değirmenliköy kilisesi apsis nişi detayı

Üçgen olarak sonlanan doğu cephesinin üst kısmında, dört yapraklı yonca formunda bir pencere açıklı̆g bulunmaktadır. Apsis açıklığı günümüzde kısmen örülerek ve demir kapı takılarak kapatılmıştır.

Kilisenin kuzey ve güney cepheleri simetrik olarak düzenlenmiștir (Görsel 7). Belirli aralıklarla yerleştirilen üçer plastır ile dört bölüme ayrılan cephelerde üçer pencere ve birer kapı açıklı̆ı 1 bulunmaktadır. Yuvarlak kemerli ve haçvari çerçeveler içerisine alınan pencereler, dikdörtgen formlu büyük açıklıklar şeklindedir. Cephelerin doğusunda, apsise yakın açılan girişler, yuvarlak kemerli olup bunlardan güneydeki örülerek, kuzeydeki ise cephenin bu bölüme bitişik olarak inşa edilen evden dolayı kapatılmıştır. Pencere çerçeveleri, duvar örgüsü ve plastır yüzeylerinde yer yer devşirme haç bezemeli taşlar kullanılmıştır. Plastırlar üzerine iç mekandaki metal gergileri desteklemek üzere birer metal kılıç yerleştirilmiştir.

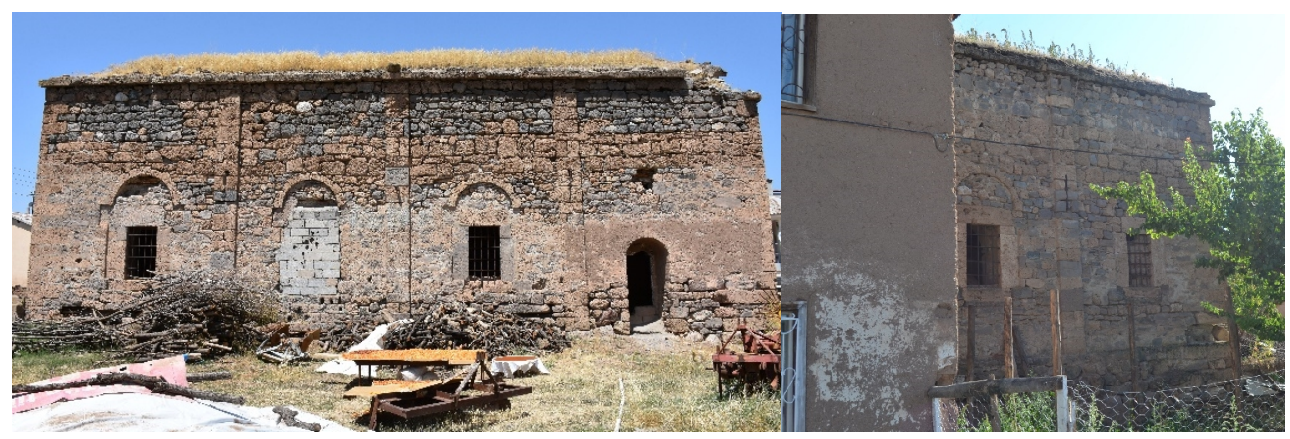

Görsel 7. Değirmenliköy kilisesi kuzey ve güney cephesi genel görünümü

Kilisenin iç mekânı cephelerdeki düzenlemeyi yansıtmaktadır. Kuzey ve güney duvarlar simetrik olup ikişer plastır ile üç bölüme ayrılmıştır. Bu bölümler çökertilmiş yüzeyler şeklinde olup birer yuvarlak kemer ile kuşatılmıştır (Görsel 8). 


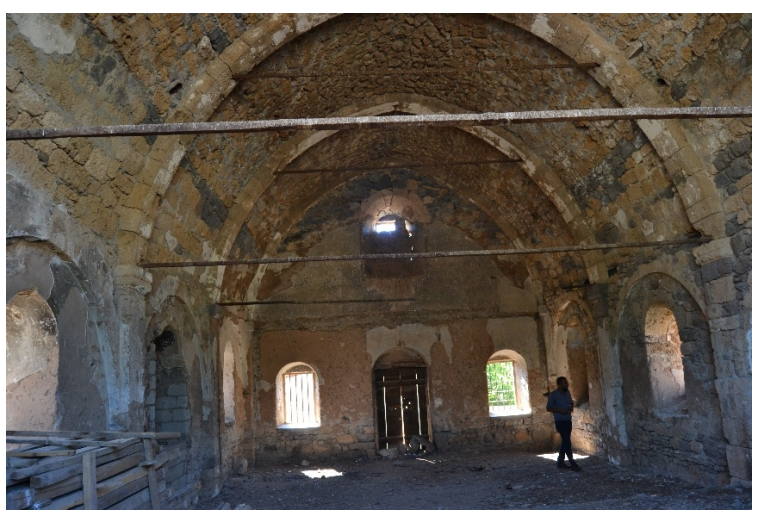

Görsel 8. Değirmenliköy kilisesi naos bölümü genel görüntüsü

Apsisin iki yanında yarım yuvarlak ve üzerleri yarım kubbe ile tamamlanmış birer litürjik nişe yer verilmiştir. Bu nişler iç mekânda yapıya üç apsisli görünümü veren taklidi pastophorion hücreleridir. Nişlerde, masa işlevi gören, birer çıkma görülmektedir (Görsel 9).

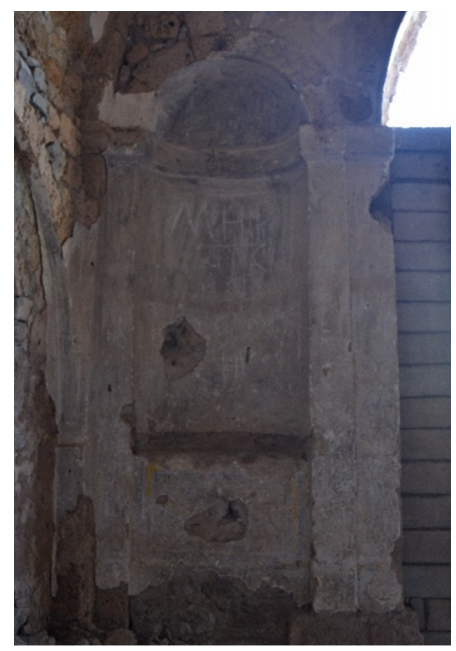

Görsel 9. Değirmenliköy kilisesi kuzey apsisi detayı

Mevcut izlerden duvarların sıvandığı ve kilisenin bir bezeme programına sahip olduğu anlaşılmaktadır. Ancak apsis ve çevresinin fresko tekniğindeki bezemeleri parçalar halinde günümüze ulaşabilmiştir. Bu bölümdeki nişlerin kemer yüzeyleri kırmızı, yeşil ve mavi renkte kıvrık dallarla (Görsel 10), aşağı kısımda ise duvar yüzeyleri sarı ve mavi renkte dikdörtgen çerçeveler içerisine alınmış baklava dilimleri ile bezenmiştir (Görsel 11).

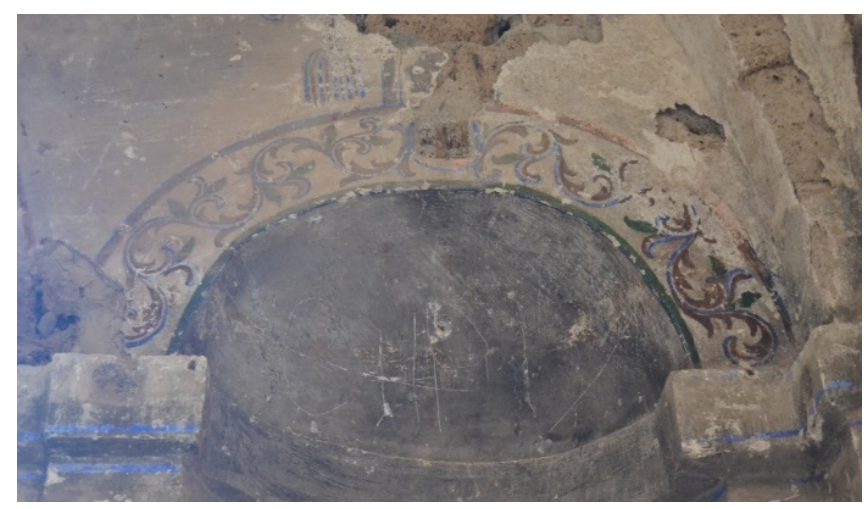

Görsel 10. Değirmenliköy kilisesi kuzey apsis kemeri süsleme detayı 


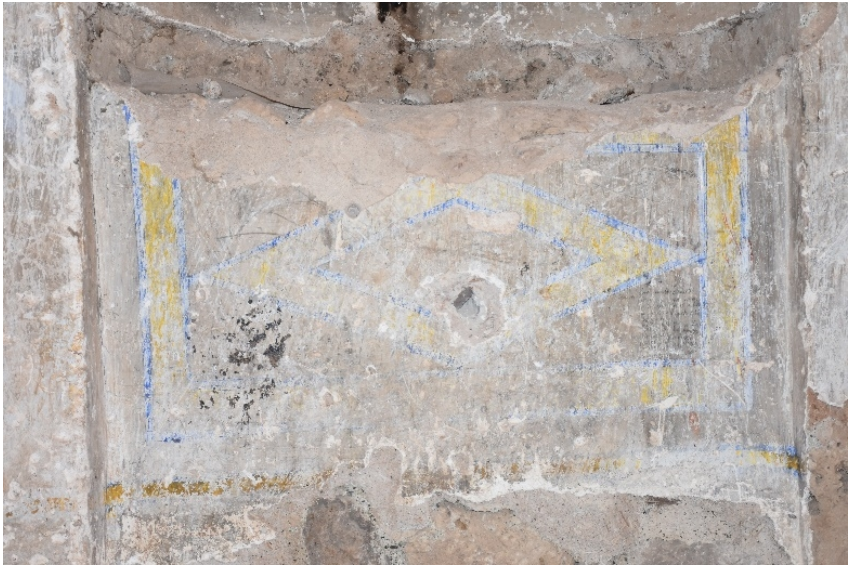

Görsel 11. Değirmenliköy kilisesi kuzey apsisi süsleme detayı

Pencereler sarı ve mavi renkte düz şeritlerden ibaret çerçeveler içerisine alınmışlarıdır (Görsel 12).

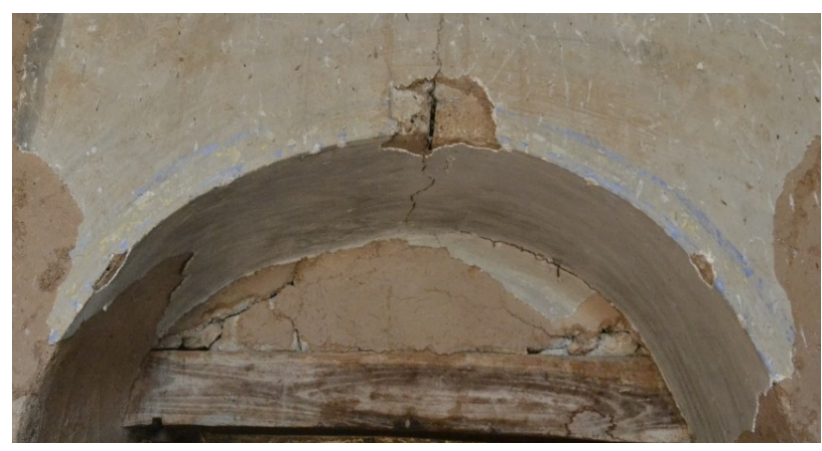

Görsel 12. Değirmenliköy kilisesi pencere süslemesi detayı

Apsis kemeri yüzeyinde mavi renkle yazılmış Ermenice bir yazıt kısmen görülebilmektedir (Görsel 13).

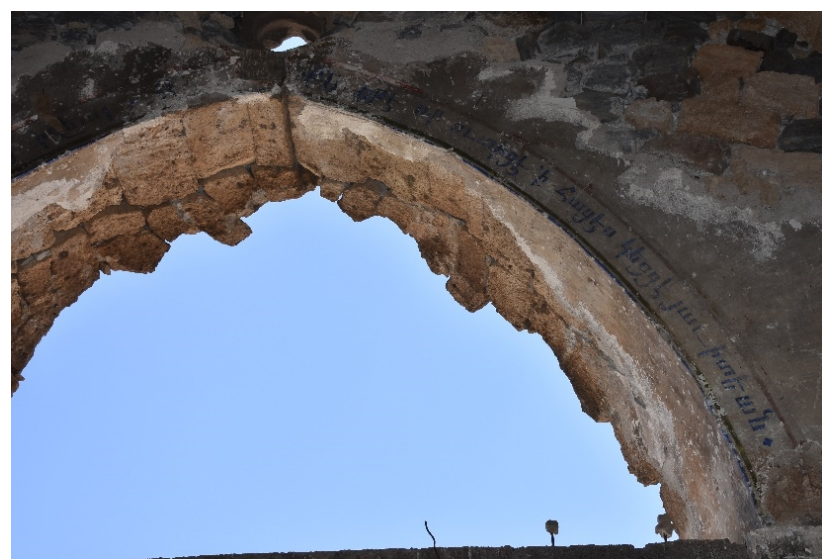

Görsel 13. Değirmenliköy kilisesi apsis kemeri ermenice yazıt

Yazının Ermenice metni ve anlamı şöyledir³:

Ermenice Metin, s.

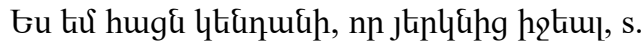

3U PU (3hunıu ..phuunnu)

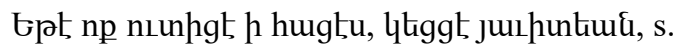

Anlamı, s.

Gökten inmiş olan diri ekmek Ben'im.

HS KS (isa Mesih)

Bu ekmekten yiyen, sonsuza dek yaşayacak. (Yuhanna 6)

\footnotetext{
${ }^{3}$ Ermenice Yazıt Sanat Tarihçisi - Ermeni Sanatı Uzmanı Dr. Elmon Haçner tarafindan okunarak Türkçeye çevrilmiştir.
} 
Yapının üst örtüsü içten beşik tonoz dıştan ise çift meyilli çatıdır. Tonozlar plastırlar üzerinden devam eden takviye kemerleri ile desteklenmiştir. Üst örtü tamamına yakın halde sağlamdır.

Kilisenin inşasında moloz taş, kaba yonu taş ve yer yer düzgün kesme taşa ilaveten haç işlemeli küçük taşlar ve haçkarlardan oluşan devşirme malzemeler kullanılmıştır. Yapı günümüzde herhangi bir işleve sahip değildir; apsis kısmı hariç büyük oranda sağlamdır.

\subsection{Yaylabaşı kilisesi}

Yapı Erzincan İli Merkez İlçesine bağlı, merkeze 12 km uzaklıkta eski adı Kiğ/Kiy (Şahin, 2017, s. 178) olan Yaylabaşı beldesinde, araziye hâkim bir alan üzerinde bulunmaktadır (Görsel 14). İnşa tarihi hakkında bilgi veren yazıt veya herhangi bir kaynak bulunmayan yapı plan ve mimari özellikleri bakımından 19.yüzyıla tarihlendirilebilir.

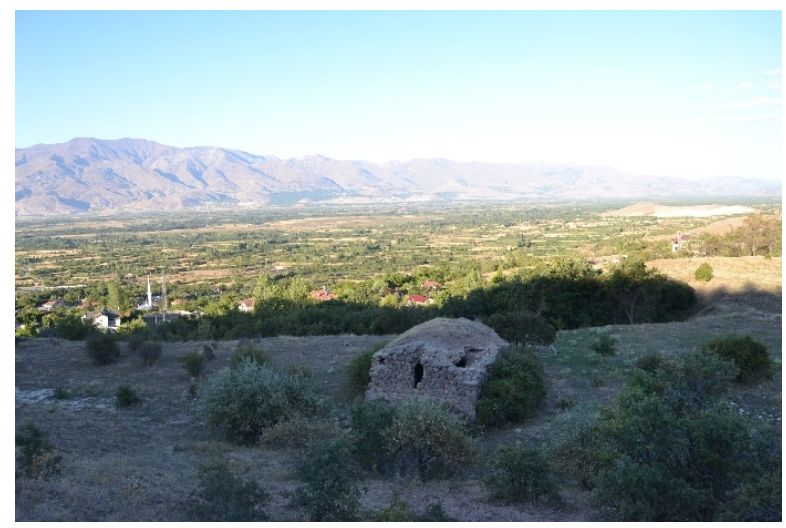

Görsel 14. Yaylabaşı kilisesi genel görünüm

Kilise yaklaşık 9,63x4,50 m. boyutlarında, dikdörtgen bir alan üzerine tek nefli, yarım daire planlı tek apsisli olarak inşa edilmiştir (Görsel 15 ve Görsel 16).

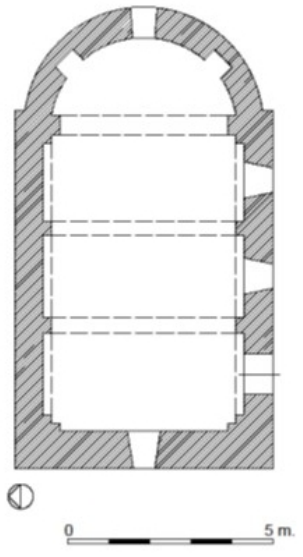

Görsel 15. Yaylabaşı köyü kilisesi planı

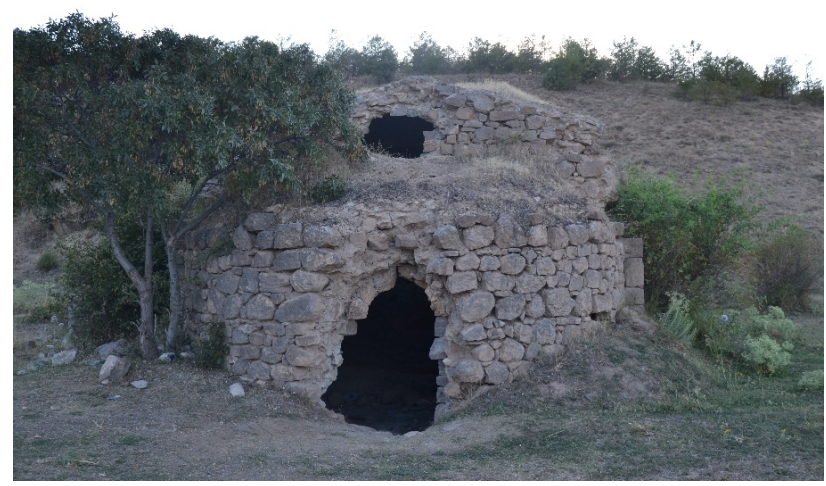

Görsel 16. Yaylabaşı kilisesi apsisi dıştan görünüm 
Güneybatı cephede açılan tek girişi bulunan yapı büyük oranda toprak içerisindedir. Güney cephede açılan iki, apsis ve apsis üzerinden devam eden doğu duvarı ve batı duvarı üst bölümünde açılan pencerelerle yapının 1şık alması sağlanmıştır. Yapının batı cephesi sade olup üst kısmında yer alan pencere açıklığı dışında içten ve diştan sade ve bölüntüsüzdür (Görsel 17).

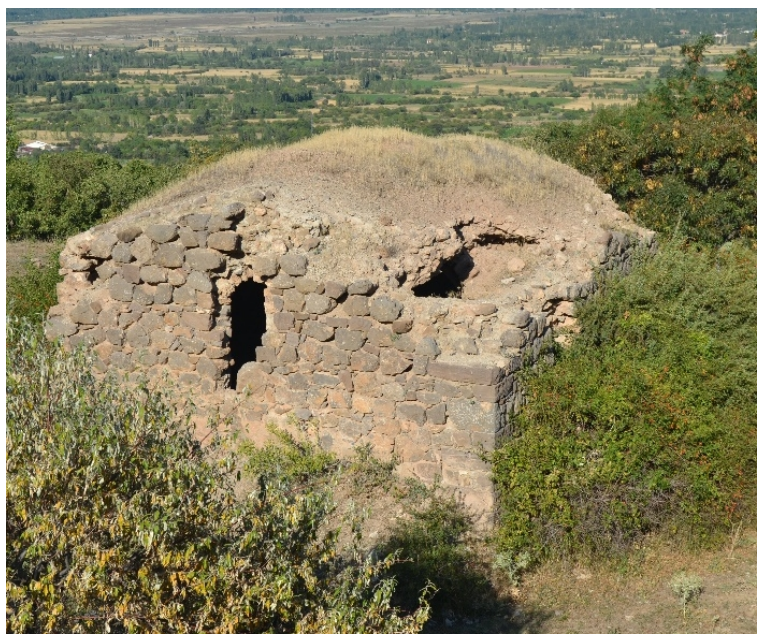

Görsel 17. Yaylabaşı kilisesi batı ve güney cepheleri genel görünüm

Kuzey cephe ise kör bir düzenlemeye sahiptir (Görsel 18). Son derece sade ve fonksiyonel olan yapının cepheleri düz ve bezemesiz olup dışarıya bağlantısı oldukça sınırlıdır.

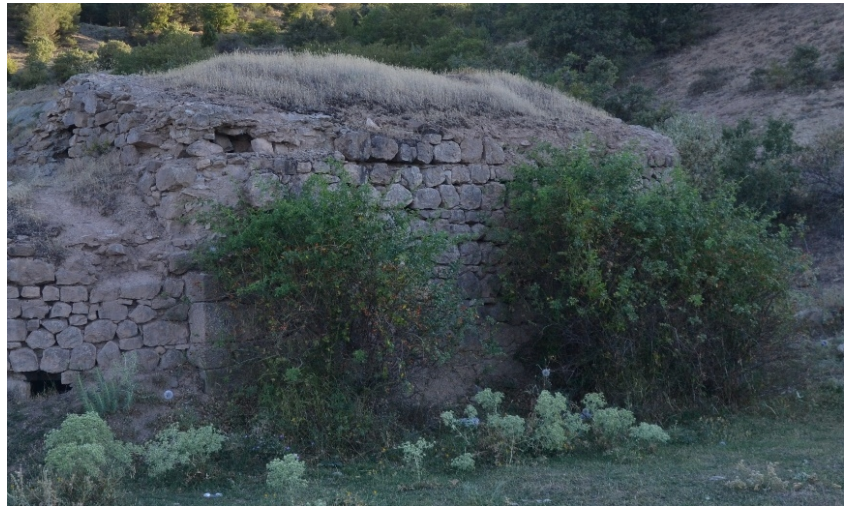

Görsel 18. Yaylabaşı kilisesi kuzey cephesi genel görünüm

İç mekânda kuzey ve güney duvarları yuvarlak kemerle üç bölüme ayrılmıştır (Görsel 19). Güney bölümde giriş ve iki pencere yer alırken kuzeydeki kemerler sağırdır.

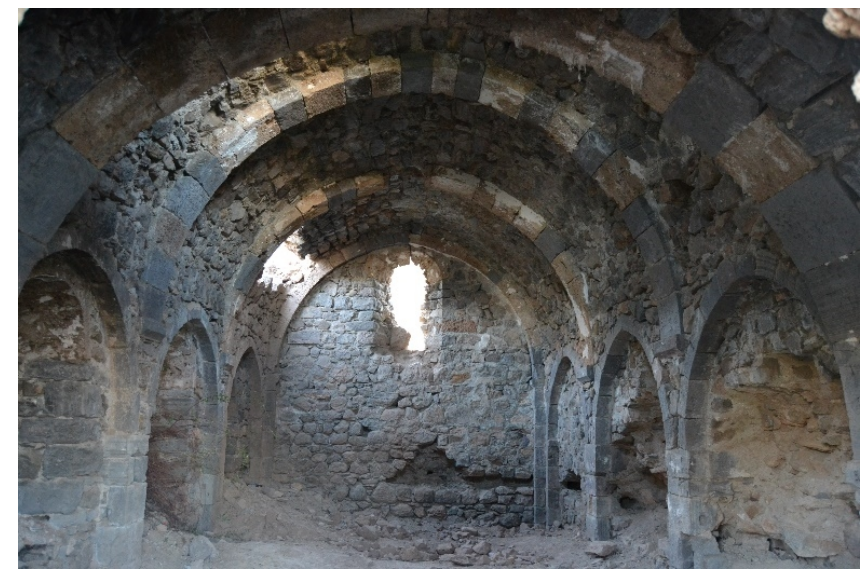

Görsel 19. Yaylabaşı kilisesi içten genel görünüm

Apsis duvarının kuzey ve güneyinde kare formlu birer niş bulunmaktadır (Görsel 20). Kilisede herhangi bir bezeme unsuruna rastlanmamıştır. Yapının üst örtüsü içten beşik tonoz, diştan günümüzde çok belirgin olmasa da, çift 
meyilli örtüdür. İnşa malzemesi kemerler, tonoz takviye kemerleri, kapı ve pencere çerçevelerinde düzgün kesme taş; diğer bölümlerde ise moloz taştır. İç mekânda zemin ve duvarların kazıldığı gözlemlenmiş, yapılan kazılar neticesinde duvar yüzeyleri parçalanmış, iç mekân toprak ve moloz dolmuştur. Büyük oranda sağlam olan yapı terkedilmiş olup herhangi bir amaç üzerine kullanılmamaktadır.

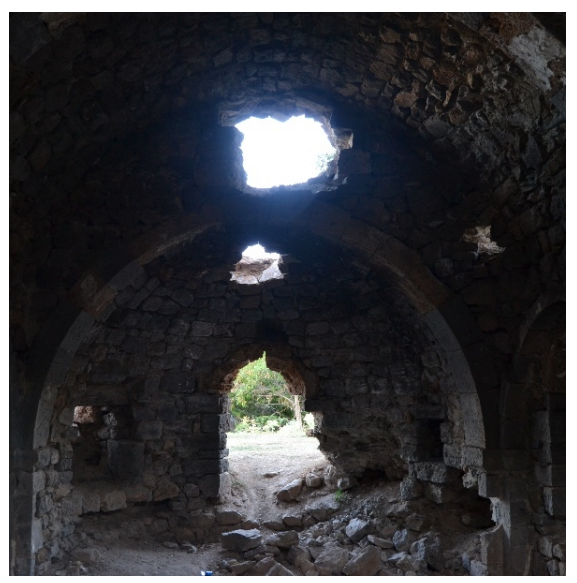

Görsel 20. Yaylabaşı kilisesi apsisi içten görünümü

\section{Karşılaş̧tırma ve Değerlendirme}

Erzincan ve çevresi Antikçağ ve Ortaçağın bir bölümünde önemli bir siyasi merkez olup dini merkezi tanrıça Anahid Tapınağı'nın (Kaymakçı, 2016, s. 276) bulunduğu Yerzınga (Erzincan) dır. Hıristiyanlığın kabulünden sonra bu tapınaklar kiliseye çevrilmiş ve bölge önemli bir dini merkez olma niteliğini sürdürmüştür (KevorkianPaboudjian, 2013, s. 457).

Ş. Dönmez’e göre Altıntepe kilisesi burada bulunan olası bir Anahit Tapınağı'ndan erken Hristiyanlık döneminde kiliseye dönüştürülmüş bir yapı olabilir. Yine Ermeni krallarından 3. Tridat, Hristiyanlığın halkı arasında yayılmasını kolaylaştırmak için Anahita heykelini yıktırmış, Tercan'daki Mithras (Mihr) tanrısına ait tapınağın topraklarını kiliseye bağışlamıştır (Kaymakçı, 2016, s. 277-278).

Erzincan ve çevresinde ortaçağdan 19. yüzyıla kadar süregelen bir kilise inşa süreci mevcut yapılardan takip edilebilmektedir. Bu anlamda Erzincan'daki önemli yapılardan biri Altıntepe Kilisesi'dir (Karaosmanoğlu, 2016, s. 272). Kilise 6. yüzyılın ortalarına İmparator Justinianos dönemine (Can, 2009, s. 5), mozaikleri ise aynı yüzyılın ortalarına tarihlendirilirken kullanılan devşirme malzemelerin aynı yerde bulunan ve daha erken bir kiliseye ait olabileceği belirtilmiştir (Can, 2011, s. 9) (Görsel 21).

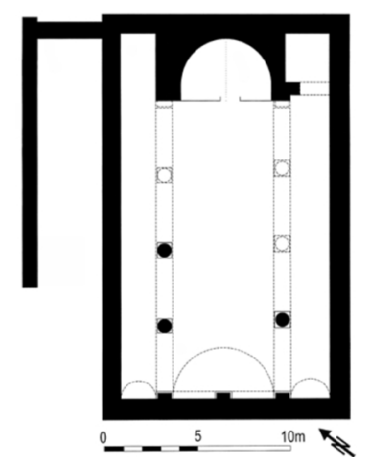

Görsel 21. Altıntepe kilisesi planı

Urfalı Mateos Vekayinamesi'nde 484 (10 Mart 1045) tarihinde Erzincan'da yaşanan büyük bir depremde bölgedeki (Egeğitaz mıntıkası) birçok kilisenin temelinden yıkıldığını ve şehrin bütünüyle harap olduğunu yazmıştır (Urfalı Mateos, 2000, s.81).

Ruy Gonzalez de Clavijo seyahatnamesinde Erzincan'da Hristiyanlara Müslüman ahaliden daha çok itibar gösterildiğini ve onların kiliselerinin camilerden büyük inşa edilmesinin Timur'a şikâyet edilmesi, sonrasında Timur'un Erzincan'daki bütün kiliselerin yıkılması emrini vermesi anlatılır (Clavijo, 1975, s.72). Bu bilgiler Erzincan'da 15. yüzyılda kiliselerin var olduğunu göstermekle beraber plan, mimari veya süsleme detaylarına girmez. 
Erzincan merkezinde yaşayan Ermeniler Surp Nışan ${ }^{4}$, Surp Yerrortutyun, Surp Sarkis, Surp Pırgiç ve Meryem Ana Kiliseleri ve okul binalarının bulunduğu dört mahallede toplanmışlardır. Çevrede bulunan Dört Hazine, Surp Kevork, Surp Nerses, Surp Giragos, Surp Hagop, Şoğagat, Surp Garabed Miamor, Surp Boğos-Bedros, Surp Tateos, Khıntragadar, Havari Tateos, Surp Asdvadzadzin ve Surp Kevork manastırlarına hac ziyareti için gelindiği; Erzincan kazasının diğer kesimlerinde ise 53 kilise, 24 manastırın var olduğu belirtilmektedir (Kevorkian-Paboudjian 2013, s. 457-458). Kamusu'l A'lam'ın Erzincan maddesine göre ise şehirde (merkez) dört kilise vardır (Sami, 1889, s. 27).

19. yüzyıl Osmanlı kayıtları Erzincan ve çevresindeki demografik yapı ile birlikte dini, sosyal ve sivil yapılar hakkında da bilgiler içermektedir. 1299 (1882) tarihli Erzurum Vilayet Salnamesi'de Refahiye'de 13 kilise olduğu kaydedilmiştir (Efe, 2016, s. 174). Eski adı Eğin olan Kemaliye ilçesi merkezi ve köylerinde kaynaklarda sadece isim olarak geçen çok sayıda kilise bulunduğu belirtilmiştir (Kevorkian-Paboudjıan, 2013, s. 379-384), (Taş, 2016, s. 385). Tercan'da yer alan kiliseler ve özellikle Abrenk Manastırı (Gündoğdu, 1998, s. 47, 252-261) Erzincan ve çevresinde, ortaçağdan itibaren Hristiyan mimarisinin örnekleri olarak okunmaktadır.

1877-78 Osmanlı-Rus Savaşı (93 Harbi) devamında toplanan Berlin Konferansı sonrasında Ermenilerin Doğu Anadolu'da bağımsız bir devlet kurmaları amaçlanmıştır. Paralelinde yaşanan isyan faaliyetleri neticesinde Anadolu'da asayiş sorunları yaşanmaya başlanmıştır. Bu dönemlerde mevcut Ermeni kiliselerinin, silah ve mühimmat deposuna çevrildiği arşiv kayıtlarında mevcuttur (Kutluğ, 2016, s. 324,326).

Çalışma kapsamında incelenen yapılar tek nefli plan düzenindedir. Oldukça sade olan bu form erken Hristiyanlık döneminden itibaren kiliselerin inşasında sıklıkla kullanılmıştır. Genelde küçük boyutlarda olan tek nefli yapıların büyük boyutlarda inşa edilen örnekleri de vardır. Üst örtüleri ahşap örtü veya takviye kemerleri olan beşik tonozlardır (Koch, 2007, s. 37).

Erken Hristiyan mimarlığının kilise mimarisi için seçtiği yapı tiplerinin erken modelleri pagan Roma mimarlığından öykünmedir. Geç antik çağda Akdeniz çevresinde oluşan ve yaygınlaşan erken Hristiyan dünyanın alıntı dinsel modelleri (Özgümüş, 1994, s. 378-379). Ermeni mimarisinde de yaygın bir şekilde kullanılmıştır. Tek nefli plan şeması Ermeni mimarisinde bilinen erken dönem yapılarında, sayıları az olmakla beraber, cemaat kiliseleri için seçilmiş plan türlerinden biri olup Akdeniz' in bütününde de yaygınlaşmıştır (Ahunbay, 1997, s. 538).

Birkaç Suriye bölgesi örneğinden bilinen Ev-kiliseler (Church-house) Ermeni mimarisinin gösterişsiz, çok azı tarihlendirilebilen, tek nefli kiliselerine model olarak görülmüştür. Görünüşte sıradan olan tek nefli şemanın, kronolojik ve topografik bir sonuçlandırmaya götürmeyen; yapıların formlarına yansıyan, çok çeşitli türleri vardır. Üst örtüleri düz veya çoğunlukla bir-iki nadiren daha fazla takviye kemeri ile desteklenen tonozlardır. Yan duvarlarda bazı Mezopotamya kilise örneklerinde de görülen nişler yer almaktadır. Apsisler genellikle içten yarım daire (4.yüzyıl), çokgen (5.yüzyıl) bazen de at nalı formda, dıştan ise düz duvar veya apsis formunu yansıtır şekildedir (Thierry, 1989, s. 52).

Ermeni mimarisinin günümüze ulaşan ilk örnekleri olan tek nefli kiliseler 4.-5. yüzyıllardan itibaren çok sayıda inşa edilmiştir. Gürcü mimarisinde 5. yüzyıldan itibaren yaygın bir şekilde inşa edilen bu küçük boyutlardaki yapılar (Kadiroğlu ve İşler, 2010, s. 23) buradan Tao-Klarceti bölgesine aktarılmış ve 11. yüzyılın sonuna kadar kullanılmıştır. Tek nefli yapılar 7. yüzyıl sonuna kadar bölüntüsüz iç mekanlara sahipken, geç dönemde duvarlara bitişik payelerle iç mekânın bölümlendirildiği, Suriye bölgesinde de görülen örneklere dönüşmüşlerdir (Bayram, 2005, s. 97).

Değirmenliköy ve Yaylabaşı kiliselerinin plan düzeni bakımından en yakın benzerleri Kemah Akça Köyü (Görsel 22), Şahintepe, Taşbulak Köyü, Gediktepe Köyü ve Kuşlu Mezrası 1 ve 2 Nolu Şapelleri ile Dolmabahçe (Vank) Mezrası (Görsel 23) ve Beklimçay Mahallesi Kiliseleridir (Kındığılı, 2015, s. 446, 448-449).

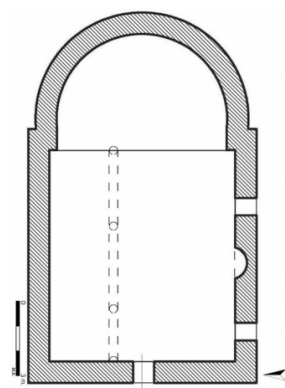

Görsel 22. Dolmabahçe (Vank) mezrası kilisesi planı

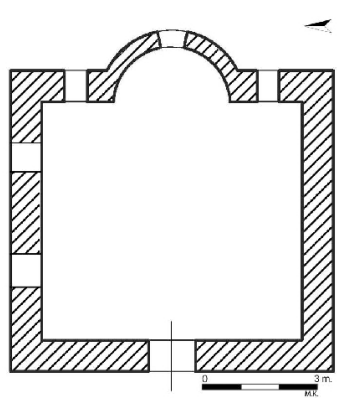

Görsel 23. Akça köyü şapeli planı

\footnotetext{
${ }^{4}$ Ortaçağda yaşamış olan ilahiyatçı Erzincanlı Hovhannes'in mezarının bulunduğu bölgedeki en eski yapı olarak geçmektedir (Bkz. KevorkianPaboudjian 2013, 457).
} 
Çoğunlukla ufak boyutlu şapellerde uygulanan tek nefli plan tipi, Gürcü mimarisinde sıklıkta uygulanmış olup apsis bölümü yarım daire veya çokgen formlarda dışarı taşıntılı veya dıştan düz duvarla sınırlanmış yarım daire planlı örneklerdir. Akaurta, Katshi, Akveneba, Dmanisi, Tetriskaro, Kuşhi Dzveli, Oltisi, Koussireti, Kemerti, Chepiaki (Görsel 24), Ekvevei, Alandza, Speti, Khvilicha, Kthsissi, Savane (Görsel 25), Mağalaant ve Agara kiliseleri kaynaklarda tespit edilen tek nefli Gürcistan'daki kiliselerinden bazılarıdır (Bayram, 2005, s. 96).

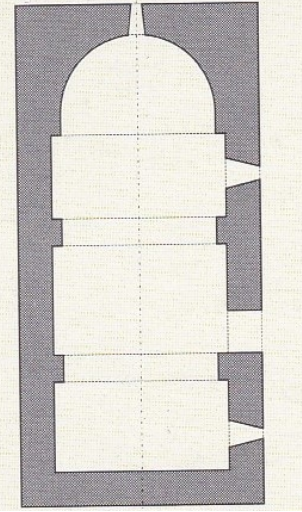

Görsel 24. Chepiaki Kilisesi Planı

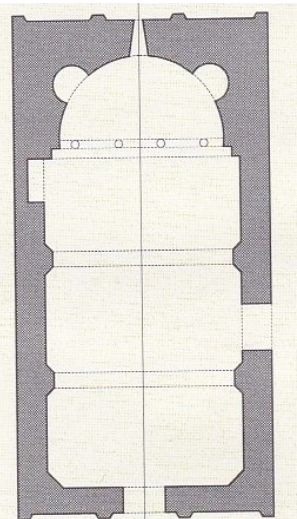

Görsel 25. Savane Kilisesi Plan

İspir Yedigöze (Kerap) ve Cankurtaran (Kayser) Köyü Şapelleri tek nefli örnekler olup örtü sistemi apsis formu, malzeme ve duvar tekniği gibi özellikler bakımından Ardahan ve Oltu'daki tek nefli şapellerle paralellik gösterirler (Aktemur ve Kukaracı, 2002, s. 13). Yusufeli, Artvin, Şavşat ve çevrelerinde tek ve üç nefli planlar sevilerek uygulanmıştır (Aytekin, 1999, s. 305).

Örnekleri Bizans dini mimarisinde de görülen basit ve yaygın bir tip olan tek nefli plan mütevazı kiliselerde ve kü̧̈ük programlı şapellerde sıklıkla kullanılmıştır (Curcic ve Loerke, 1991, s. 409-410; Curcic, 1991, s. 459). Bununla birlikte bu kiliselerin önemli bir özelliği de merkezi yerlerden ziyade taşrada görülmeleridir.

Aleksandru'ya (1996) göre, tek nefli plan İstanbul yapılarında, Bizans dönemi sonrasında pek kullanılmamıştır. İstanbul'da 19. yüzyılda inşa edilen kiliselerden Kurtuluş Hagios Elevtherios, Eğrikapı Hagios Kyriakos, Tarabya Hagios Konstantinos-Hagia Heleni, Ortaköy Hagios Georgios Kiliseleri tek nefli örneklerdir. Ege, Kapadokya, Akdeniz ve Karedeniz bölgelerinde de bu türün örnekleri sıklıkla karışımıza çıkmaktadır (Okuyucu, 2013, s. 499500).

Süsleme özellikleri açısından değerlendirildiğinde, Değirmenliköy Kilisesinin içten fresk tarzında bezemelere sahip olduğu mevcut izlerden anlaşılmaktadır. Kalıntılar bitkisel ve geometrik bezemelere ve yazı kuşaklarına işaret etmekte, figürlü bezemenin var olup olmadığına dair bir ipucu vermemektedir. Buna karşın Yaylabaşı Kilisesi ise duvarlarının içten sıvalı olduğuna dair nadir izler taşımakla birlikte herhangi bir bezeme unsuruna sahip değildir.

Mevcut süslemeler gerek Ermeni, gerekse Rum kiliselerinde geç döneme özgü olmakla birlikte daha basit işçilik sunarak sıklıkla karşımıza çıkmaktadır. Orta ve Doğu Karadeniz Bölgesi 19. yüzyıl Rum Ortodoks Kiliselerinde iç mekânlar, sıva üzerine kök boyalarla yapılan, kıvrık dallar, asma dalları, üzüm yaprakları ve çiçek motiflerinden oluşan bitkisel; düz ve basit çizgiler, zincirek motifleri, baklava dilimleri, üçgenler, daireler vb. şekillerden ibaret geometrik motiflerle bezenmiştir. Hem bölgede, hem de Anadolu'nun diğer yörelerinde bulunan kiliselerde iç mekânda ve diş mimaride görülen vazgeçilmez unsurlardan birisi de haç motifidir (Okuyucu Yılmaz, 2015, s. 143).

Çalışma kapsamında ele alınan yapılardan Yaylabaşı kilisesi dış mimarisi bakımından da herhangi bir bezemeye sahip değildir. Değirmenliköy kilisesi batı cephesi düzenlemesi ile estetik bir görünüm sunmaktadır. Giriş kademeli haç, pencereler ise yuvarlak kemerli çerçeveleri içerisine alınmıştır. Cephede özenle konumlandırılan haçlı taşlar devşirme olup çevreden toplanarak yapıda kullanılmıştır 5 .

Kelime anlamı haçlı taş anlamına gelen haçkarlar, Ermeni sanatı içerisinde 9. yüzyılda ortaya çıkıp 18. yüzyılın sonuna kadar üretilmiştir (Petrosyan, 2001, s. 60). Haçkarlar açık havada veya bir dini yapının yakınında çoğunlukla bir kaide üzerinde yükselirler. Bazen dini yapıların duvarlarına iliştirilen haçlı taşlar, bazen de kaya üzerine hacılar tarafindan basit çiziklerle oluşturulan haç şekilleri olarak yapılmıştır (Thierry, 1989, s. 123).

\footnotetext{
${ }^{5}$ Köyde yaşayan yaşlı kişiler ile yapılan görüşmede bu taşlara benzeyen taşlardan çevrede çok olduğu bilgisi alınmıştır.
} 
Tercan'da bulunan Abrenk (Aparank) manastırı haçkarları (Thierry, 1989, s. 245), Erzincan örneklerinin en iyi bilinenleri olmakla birlikte Ermeni dini yapılarının bulunduğu çoğu yerde haçkar örneklerini görebilmek mümkündür.

Değirmenliköy Kilisesi cephelerinin muhtelif yerlerinde çok sayıda haçlı taş bulunmaktadır. Bu taşların, inşa sırasında özellikle haçkar fonksiyonu gereği olarak mı, yoksa devşirme malzeme olarak mı kullanıldığı düşünülmesi gereken bir husustur. Haçkarlar, yapıların duvarlarına özgün halleri ile orijinal inşa süreçlerinde dahil edilebilirler. Fakat Değirmenliköy kilisesi haçkarlarının birçoğu, taşın yerleştirildiği alana göre şekillendirilmiştir. Batı girişin sağındaki lento bir haçkar olmakla birlikte yazıtının kesildiği görülmektedir. Yine aynı pencerenin sövesinde kullanılan haçkar ters yerleştirilmiştir. Apsis içerisinde yer alan kuzey nişin üst kısmı bir haçkardır. Orijinal taş yeniden şekil verilmek suretiyle alınlıkta hazır malzeme olarak değerlendirilmiştir. Güney cephede örülerek kapatılan orta pencerenin sol köşesinde de bir haçkar parçası kullanılmıştır. Yine güney cephede duvar örgüsünün alt kısmında dıştan sal taş gibi görünen, bu bölümdeki duvar örgüsü kısmen boşalması neticesinde görülebilen, kazınarak oluşturulmuş sade bir haçkar, salt duvar örgü malzemesi olarak kullanılmıştır.

\section{Sonuc}

Erzincan İli Merkez İlçesine bağlı Değirmenliköy ve Yaylabaşı mevkiinde bulunan yapılar tek nefli plan şemasında inşa edilmişlerdir. Yapılardan Değirmenliköy Kilisesi 9.80 x 16.90 m.boyutları ile daha büyük bir yapı iken Yaylabaşı kilisesi 9,63 x 4,50m boyutlarında olup daha küçüktür. Geç antik çağda Hristiyanların ibadethane ihtiyaçları pagan tapınaklardan evrilen yapılarla sağlanmış, sonrasında Hıristiyan dini mimarisi kendisine özgü bir kimliğe sahip olmuştur. Zamana ve tahribatlara direnemeyen süslemeler hakkında kısıtlı görseller, özellikle Değirmenliköy kilisesinde, bir bezeme programının varlığına somut işaretlerdir. İnşa malzemesi olarak taş malzeme yanı sıra yine Değirmenliköy kilisesi özelinde Ermeni mimarisine özgü haçkarlar devşirilerek kullanılmıştır. Yapıların günümüzde kısmen harap, bakımsız ve kaçak kazılarla hırpalanmış vaziyettedirler. Çalışma kapsamında ele alınan ve Ermeni dini mimarisinin birer örneği olan yapılar, tek nefli plan şemasının Ermeni dini mimarisi içerisindeki yeri ve gelişimine uyan mütevazı örneklerdir.

\section{Kaynakça}

Ahunbay, M. (1997). Ermeni mimarlığı ve sanatı. Eczacıbaşı Sanat Ansiklopedisi C.1 (s. 537-542) içinde. İstanbul: Yap1 Endüstri Merkezi.

Aktemur, A. M., \& Kukarac1, İ. U. (2002). İspir ve çevresi kiliseleri. Atatürk Üniversitesi Güzel Sanatlar Enstitüsü Dergisi, Say1 8, 7-29.

Akyel, S. (2016). XIX. yüzyılda Eğin kazasının demografik yapısı üzerine bir değerlendirme. H. Akın (Ed.), Uluslararası Erzincan Sempozyumu Bildiriler Kitabı: Cilt 1 (s. 55-65) içinde. Erzincan: Erzincan Üniversitesi.

Aleksandru, E. (1996). 19. yüzyılda İstanbul Rum Ortodoks Kiliseleri (Yüksek Lisans Tezi). İstanbul Teknik Üniversitesi Sosyal Bilimler Enstitüsü, İstanbul. YÖK tez veri tabanından erişildi (Tez No. 53293).

Aslay, S. E. (2017). Erzincan Değirmenliköy Kilisesi’nin 1939 Erzincan depremi davranışının apsis hasarı üzerinden incelenmesi (Yüksek Lisans Tezi). Erzurum Teknik Üniversitesi Fen Bilimleri Enstitüsü İnşaat Mühendisliği Anabilim Dalı, Erzurum. YÖK tez veri tabanından erişildi (Tez No. 486666).

Aytekin, O. (1999). Ortaçağdan Osmanlı dönemi sonuna kadar Artvin'deki mimari eserler. Ankara: Kültür Bakanlığı Yayınları.

Bayram, F. (2005). Artvin’deki Gürcü manastırlarının mimarisi. İstanbul: Ege Yayınları.

Bozkurt, G. (1989). Alman-İngiliz belgelerinin ve siyasi gelişmelerin ışı̆̆ altında Gayrimüslim Osmanlı vatandaşlarının hukuki durumu (1893-1914). Ankara: TTK Yayınevi.

Can, B. (2009). Erzincan-Altıntepe church with mosaic. Journal of Mosaic Research, 3, 3-15.

Can, B. (2011). Technical stylistic, 1conographic evaluation and dating of mosaics of Altıntepe Church. M. Şahin (Ed.), XI. International Colloquium on Ancient Mosaics October 16th-20th 2009 (s. 225-234) içinde. Bursa.

Clavijo, R. G. (1975). Timur devrinde Semerkand'a seyahat (Ö. R. Doğrul, Çev.). İstanbul: Nakışlar Yayınevi.

Curcic, S. (1991). Church plan types. The Oxford Dictionary of Byzantium içinde (Volume1, s. 459). New York: Oxford University Press.

Curcic, S., \& Loerke, W. (1991). Chapel. The Oxford Dictionary of Byzantium içinde (Volume1, s. 409-410). New York: Oxford University Press. 
Çakaloğlu, C. (1999). Erzincan ve çevresinde Ermeni olayları (1890-1896). Atatürk Üniversitesi Türkiyat Araştırmaları Enstitüsü Dergisi, 13, 299-304.

Efe, A. (2016). Sicill-i Ahvâl kayıtlarına göre Refahiyeli memurlar. Uluslararası Erzincan Sempozyumu Bildiriler Kitabı: Cilt 1 (s. 173-184) içinde. Erzincan: Erzincan Üniversitesi.

Ercan, Y. (2001). Osmanl yönetiminde Gayrimüslimler kuruluştan Tanzimat'a kadar sosyal, ekonomik ve hukuki durumlarl. Ankara: Turhan Kitapevi.

Evliya Çelebi. (2010). Günümüz Türkçesiyle Evliya Çelebi Seyahatnamesi: Bağdad-Basra-Bitlis-DiyarbakırIsfahan-Malatya-Mardin-Musul-Tebriz-Van, 4. Cilt, 1. Kitap. (S. A. Kahraman ve Y. Dağl1, Haz.). İstanbul: Yap1 Kredi Yayınları.

Gündoğdu, H. (1998). Tarihi kalıntılar. Cumhuriyetin 75. Yllinda Tercan, 215-261.

İnbaşı, M. (2009). Erzincan kazası (1642 tarihli Avarız rehberine göre). Atatürk Üniversitesi Türkiyat Araştırmaları Enstitüsü Dergisi, 41, 189-214.

Kadiroğlu, M., \& İşler, B. (2010). Gürcü sanatının ortaçağg, Ankara: Onur Matbaacıllk.

Kara, R. (2016). "Erzincan Adı Üzerine”, Uluslararası Erzincan Sempozyumu Bildiriler Kitabı, Cilt 1, 563-571.

Karaosmanoğlu, M. (2016). Erzincan/Altıntepe Kalesi'nin Anadolu arkeolojisindeki yeri ve önemi. Uluslararası Erzincan Sempozyumu Bildiriler Kitabı: Cilt 1 (s. 267-273) içinde. Erzincan: Erzincan Üniversitesi.

Kaymakçı, S. (2016). Antikçağ'da Erzincan ve Çevresindeki Tapınımlar-Kültter. Uluslararası Erzincan Seтроzуити Bildiriler Kitabl: Cilt 1 (s. 275-282) içinde. Erzincan: Erzincan Üniversitesi.

Kevorkian, R. H., \& Paboudjıan, P. B. (2013). 1915 öncesinde Osmanlı Imparatorluğu'nda Ermeniler. İstanbul: Aras Yayınc1lik.

Kındığılı, M. L. (2015). Ortaçağ’dan günümüze Kemah ve köylerindeki kültür varlıkları (Doktora Tezi). Atatürk Üniversitesi Sosyal Bilimler Enstitüsü Sanat Tarihi Anabilim Dalı, Erzurum. YÖK tez veri tabanından erişildi (Tez No. 429643).

Koch, G. (2007). Erken Hıristiyan sanatı. İstanbul: Arkeoloji ve Sanat Yayınları.

Kutluğ, E. (2016). Osmanlı arşivi belgeleri ile Birinci Dünya Savaşı yıllarında Erzincan. Uluslararası Erzincan Sempozyumu Bildiriler Kitabı: Cilt 1 (s. 321-333) içinde. Erzincan: Erzincan Üniversitesi.

Mateos. (1987). Urfalı Mateos Vekâyi-Nâmesi (952-1136) ve Papaz Grigor'un zeyli (1136-1162) (H. D. Andreasyan, Çev.). Ankara: Türk Tarih Kurumu Basımevi.

Miroğlu, İ. (1995). Erzincan. TDV İslam Ansiklopedisi içinde (Cilt 11, s. 318-321). İstanbul: Türk Diyanet Vakfi Yayınları.

Okuyucu Yılmaz, D. (2015). Orta ve Doğu Karadeniz bölgesi 19. yüzyıl Rum Ortodoks kiliseleri figürlü Freskoları üzerine bir değerlendirme. Atatürk Üniversitesi Edebiyat Fakültesi Sosyal Bilimler Dergisi, 55, 127-167.

Okuyucu, D. (2013). Orta ve Doğu Karadeniz bölgesi Rum kiliseleri (Doktora Tezi). Atatürk Üniversitesi Sosyal Bilimler Enstitüsü Sanat Tarihi Ana Bilim Dalı, Erzurum. YÖK tez veri tabanından erişildi (Tez No. 326842).

Özgümüs, F. (1994). Anadolu'da kiliseye çevrilmiș Yunan ve Roma tapınakları (Doktora Tezi). İstanbul Üniversitesi Sosyal Bilimler Enstitüsü Arkeoloji ve Sanat Tarihi Bölümü Bizans Sanatı Anabilim Dalı, İstanbul.

Parlak, N. (2016). Klasik kaynaklarda Erzincan'ın yeri ve önemi. Uluslararası Erzincan Sempozyumu Bildiriler Kitabı: Cilt 1 (s. 355-365) içinde. Erzincan: Erzincan Üniversitesi.

Pekak, M. S. (2009). Kappadokia bölgesi Osmanlı dönemi kiliseleri: örnekler, sorunlar, öneriler. METU JFA, 26(2), 249-277.

Petrosyan, H. (2001). The Khachkar or cross-stone. L. Abrahamian, N. Sweezy, \& S. Sweezy (Ed.), Armenian folk arts, culture, and ldentity içinde (s. 60-70). USA: Indiana University Press.

Polo, M. (2003). Dünyanın hikâye ediliş̧, Harikalar kitabı 1 (I. Ergüden, Çev.). İstanbul: İthaki Yayınları.

Sami, Ş. (1889), Kamus'ul A'lam. İstanbul: Mihran Matbaası.

Şahin, T. E. (2017). Erzincan, yukarı ülkenin kadim cenneti. Ankara: Erzincan Valiliği Kültür Yayınları. 
Taş, N. F. (2016). Osmanlı devleti'nin Meşrûtiyyet döneminde Erzincan'da eşkıyâlık. Uluslararası Erzincan Sempozyumu Bildiriler Kitabl: Cilt 1 (s. 377-389) içinde. Erzincan: Erzincan Üniversitesi.

Thierry, J. M. (1989). Armenian art. New York: Harry N Abrams Inc.

Turan, Ş. (1963). Osmanlı teşkilatında hassa mimarları. Tarih Araştırmaları Dergisi, 1(1), 157-202.

Ubicini, M. A. (2010). Letters on Turkey: An account of the religious, political, social and commercial condition of Ottoman Empire. Part I: Turkey and the Turks. Part II: the Raiabs (L. Easthope \& J. Murray, Çev.). London: The British Library. (Orijinal eser yayın tarihi: 1856).

\section{Görsel Kaynakçası}

Görsel 1-20. Demet Okuyucu Yılmaz. 2018 yılı arazi çalışmaları sonucu elde edilen verilerle oluşturulmuş şahsi arşiv.

Görsel 21. Altıntepe Kilisesi Planı. (2009). Birol Can şahsi arşivi.

Görsel 22. Dolmabahçe (Vank) Mezrası Kilisesi Planı. (2015). M. Lütfi Kındığılı şahsi arşivi.

Görsel 23. Akça Köyü Şapeli Planı. (2015). M. Lütfi Kındığılı şahsi arşivi.

Görsel 24. Chepiaki Kilisesi Planı. (2005). Fahriye Bayram şahsi arşivi.

Görsel 25. Savane Kilisesi Planı. (2005). Fahriye Bayram şahsi arşivi. 